\title{
Consistency in migration strategies and habitat preferences of brown skuas over two winters, a decade apart
}

\author{
Ana P. B. Carneiro, ${ }^{1,2,}$, Andrea Manica ${ }^{1}$, Thomas A. Clay ${ }^{1,2}$, Janet R. D. Silk ${ }^{2}$, \\ Michelle King ${ }^{2}$, Richard A. Phillips ${ }^{2}$ \\ ${ }^{1}$ Department of Zoology, University of Cambridge, Downing Street, Cambridge CB2 3EJ, UK \\ ${ }^{2}$ British Antarctic Survey, Natural Environment Research Council, Madingley Road, High Cross, Cambridge CB3 0ET, UK
}

\begin{abstract}
At-sea movements and activity patterns of brown skuas Stercorarius antarcticus lonnbergi from South Georgia were analysed in 2 winters, a decade apart, to examine the degree of consistency in migration strategies and habitat preferences during the non-breeding and prelaying exodus periods. Oceanographic habitat preferences of tracked skuas were determined using a robust model accounting for availability. At the population level, brown skuas were broadly consistent in their choice of wintering areas and habitat preferences, although the distribution extended farther east in 2012 than in 2002. Skuas preferred areas associated with static oceanography (bathymetric features) both during the non-breeding and pre-laying periods, which may explain the consistency between years in habitat use. There was no significant effect of year on departure dates from South Georgia, but birds returned earlier to the colony in 2002. Migration schedules varied according to breeding status, with failed birds departing earlier than birds that bred successfully. Although failed birds travelled farther from the colony, there was little variation in dates of return. In general the timing of movements was similar between sexes, but females were more likely than males to engage in a pre-laying exodus. Brown skuas spent a much higher proportion of time sitting on the water than other seabirds during both the non-breeding and prelaying exodus periods, and the number of flight bouts per day was surprisingly low. The selection of static features by brown skuas may indicate that skuas may have less flexibility to track environmental changes than species that use dynamic cues.
\end{abstract}

KEY WORDS: Annual variability · Biologging · GAMs · Geolocation · GLS · Habitat selection · Modelling $\cdot$ Seabird

Resale or republication not permitted without written consent of the publisher

\section{INTRODUCTION}

Seabirds spend most of their lives at sea, only returning to land to breed. Understanding the factors that influence their marine distribution and habitat preferences is therefore essential for mitigating threats at sea, including the establishment of an effective, evolving network of protected areas that will safeguard against future biodiversity loss (Block et al. 2011, Frederiksen et al. 2012). The open ocean is a dynamic environment, and seabirds frequently target areas of higher prey availability (Pinaud \& Weimerskirch 2005, Nur et al. 2011, Quillfeldt et al. 2013). These regions are often characterised by local physical features or processes, including eddies, frontal systems, upwelling zones and shelf breaks, that increase primary production or serve to aggregate animals at higher trophic levels (Wakefield et al. 2009, Kappes et al. 2010, Louzao et al. 2011a, Pinet et al. 2011). Reductions in size and improvements in battery-life and functionality of tracking devices since the 1990s have greatly improved our knowl- 
edge of at-sea distribution patterns and behaviour of marine predators (Phillips et al. 2007). More recently, studies that combine tracking data with remotely sensed environmental data in habitat models have provided key insights into the oceanographic factors that drive the distribution of seabirds (Péron et al. 2010, Louzao et al. 2011b, Wakefield et al. 2011, Quillfeldt et al. 2015).

A limitation of many biologging studies is that data are available from relatively few individuals tracked over short periods of time (Žydelis et al. 2011). In addition, as most physical characteristics of the ocean are dynamic at varying temporal and spatial scales, prey, and hence predator, distributions are expected to vary accordingly (Pinaud et al. 2005, Žydelis et al. 2011, Quillfeldt et al. 2013). Although there is evidence in some species that individuals can change their non-breeding destination (e.g. Dias et al. 2011), the general trend appears to be for high regional site fidelity among migrant seabirds (Croxall et al. 2005, Phillips et al. 2005, 2006, Guilford et al. 2011, Thiebot et al. 2011, Yamamoto et al. 2014). There is also good evidence for high year-to-year consistency in migration schedules (timing and duration of events) for birds that are faithful to their winter destinations (Croxall et al. 2005, Phillips et al. 2005, Dias et al. 2011, Yamamoto et al. 2014). It is important to note, however, that in all these studies, individuals were tracked for successive years, when conditions may be more similar than after longer intervals.

Individuals from the same breeding population frequently use multiple regions or habitats during their non-breeding period (Phillips et al. 2005, Dias et al. 2011, Kopp et al. 2011). These alternative strategies are often associated with differences in age, breeding status, sex, or individual preferences (Phillips et al. 2005, Ramírez et al. 2013, Quillfeldt et al. 2015). Migration schedules can also vary, especially in relation to sex or prior breeding outcome (Phillips et al. 2005, Bogdanova et al. 2011, Catry et al. 2013a). In addition, some non-breeding regions may be used by a small minority of animals: only 2 of 34 black-browed albatrosses Thalassarche melanophris tracked from South Georgia did not migrate to the Benguela Upwelling but instead spent the non-breeding period on the Patagonian Shelf or in Australian waters (Phillips et al. 2005); and, only 2 of 39 south polar skuas Stercorarius maccormicki tracked from King George Island wintered in the southern hemisphere, one off Peru and the other west of Gough Island (Kopp et al. 2011). Thus, to better identify core areas for the entire population, and also to improve the accuracy of predicted distributions based on observed habitat preferences accounting for future environmental changes, tracking studies should ideally involve large numbers of individuals in multiple years (Hindell et al. 2003, Soanes et al. 2013).

The brown skua Stercorarius antarcticus lonnbergi breeds on islands from the subantarctic to the Antarctic continent and is one of the main terrestrial consumers, primarily feeding on other seabirds and seal carrion (Phillips et al. 2004a, Carneiro et al. 2014 , 2015). To date, non-breeding ranges of brown skuas have been inferred from the distribution of just 6 birds tracked from South Georgia during the winter of 2002 using global location sensors (GLS); these birds dispersed over deep, subantarctic and mixed subantarctic-subtropical waters within the Argentine Basin (Phillips et al. 2007). However, stable isotope analyses of feathers from a larger sample suggested that some individuals may use continental shelf or shelf-slope waters (Phillips et al. 2009). In the present study, GLS-immersion loggers were deployed on adult brown skuas from the same population, but different individuals, in order to: (1) assess if distribution or other aspects of migration strategies have changed in the $10 \mathrm{yr}$ since the first study, (2) identify key habitat preferences, (3) better characterise the migration period in terms of timings, durations and travel distances, (4) investigate differences in distribution and migration characteristics in relation to sex and recent breeding performance, (5) compare atsea activity patterns between male and female nonbreeders, and (6) describe the pre-laying exodus.

\section{MATERIALS AND METHODS}

This study was carried out during 2 non-breeding seasons a decade apart on brown skuas Stercorarius antarcticus lonnbergi at Bird Island, South Georgia $\left(54^{\circ} 00^{\prime} \mathrm{S}, 38^{\circ} 03^{\prime} \mathrm{W}\right)$. Bird Island is probably the most densely populated colony of brown skuas in the world, with 132 nesting pairs $\mathrm{km}^{-2}$ (Phillips et al. 2004a). A GLS-only logger (weight 7 g) or a combined GLS-immersion logger (weight $9 \mathrm{~g}$ ) was deployed in austral summer 2001/2002 on 28 breeding adults. Combined GLS-immersion loggers (weight $1.5 \mathrm{~g}$ ) were deployed on 25 breeding adults, none of which were in the earlier sample, in the same study area in austral summer 2011/2012. All loggers were attached with a cable-tie to a British Trust for Ornithology (BTO) metal ring on the tarsus and recovered after a year. Skuas were captured on the ground by hand or using a hand net or noose pole. Only data encompassing the non-breeding and pre-laying exo- 
dus periods are analysed here. The non-breeding period was defined as the time from the start of the outward migration to the return to the breeding grounds the following season and was assessed for each individual using both location and activity data. Departure date was identified as that immediately prior to a directed movement away from South Georgia and consecutive nights thereafter that were spent largely on the water, whereas return date was that preceding the first night spent dry (on land). As skuas with eggs or chicks at South Georgia never forage at sea, after the initial return from migration, subsequent periods of consecutive days with intervening nights spent largely on the water were classified as pre-laying trips (Phillips et al. 2007, Carneiro et al. 2014).

Light data were analysed using the BASTrak suite (British Antarctic Survey, Cambridge, UK) based on times of sunset and sunrise estimated from thresholds in light curves; latitude was derived from day (night) length, and longitude from the time of local midday (midnight) in relation to Greenwich Mean Time and day of the year, providing 2 locations per day with an average accuracy of $186 \pm 114 \mathrm{~km}$ (Phillips et al. 2004b). Locations were excluded for 2 to $4 \mathrm{wk}$ around the equinoxes, when latitudes were unreliable. All other analyses were carried out using $\mathrm{R}$ software (R Core Team 2014). A hierarchical state-space model fitted to data from multiple animals was used to filter and correct observed locations for logger error (Jonsen et al. 2013, Gutowsky et al. 2014). Estimates of uncertainty for each latitude and longitude are required in order to fit state-space models (Winship et al. 2012). As there are no relevant published data for skuas from double-tagging experiments, a fixed geolocation error (SD of latitudinal and longitudinal error: $1.66^{\circ}$ and $1.82^{\circ}$, respectively; Phillips et al. 2004b) derived from concurrent deployment of satellite transmitters and GLS loggers on albatrosses was used as an estimate of uncertainty. The state-space model was fitted using Markov Chain Monte Carlo (MCMC) sampling in the bsam package (Jonsen et al. 2015). Two chains of 5000 samples from the joint posterior probability distribution were obtained after discarding the initial burn-in period of 100000 samples and retaining every 20th of the remaining samples. Convergence was assessed visually by checking trace, density and autocorrelation plots (Pollet et al. 2014). After processing, locations derived from curves with apparent interruptions around sunset and sunrise which were not filtered by the state-space model were removed after visualisation in ArcGIS v. 10.2.2.
Changes in the spatial distribution of brown skuas between non-breeding and pre-laying periods in 2002 and 2012 were investigated by producing $95 \%$ (general use) and $40 \%$ (core) utilization distributions (UDs) for each individual, using kernel analysis with a cell size of $50 \mathrm{~km}$ and a fixed smoothing parameter (h) of $200 \mathrm{~km}$ (Phillips et al. 2006). The $40 \%$ density contour was selected by noting where the relationship began to increase exponentially when incremental changes in UDs were plotted against the size of the total area identified, which is considered to be a reliable approach for defining core areas of activity (Lascelles et al. 2016). Population core and general use areas were created by merging individual UDs, assigning them equal weighting. Individual overlaps were quantified using Bhattacharyya's affinity, which ranges from 0 (no overlap) to 1 (identical UDs) and is considered to be the most appropriate index for quantifying the degree of similarity among UD estimates (Fieberg \& Kochanny 2005). Kernel analysis and individual overlap calculations were carried out using the adehabitatHR package (Calenge 2006). Analyses of similarity (ANOSIM) were used to test for significant differences in the 95 and $40 \%$ overlaps by year, sex, and breeding status (failed or successful birds in the year of deployment) using the vegan package (Oksanen et al. 2015). The dissimilarities between the UDs were included in a distance matrix (also known as a dissimilarity matrix). ANOSIM uses a bootstrap randomization procedure to test for differences between groups; if 2 groups are different, then dissimilarities between the groups should be greater than those within the groups (Oksanen et al. 2015). $R$ values from ANOSIM are equivalent to a correlation coefficient and range from -1 to 1 , with 0 indicating completely random grouping.

Oceanographic habitat preferences of the tracked skuas during the non-breeding and pre-laying periods were determined using a case-control approach in binomial generalized additive models (GAMs). For each animal location, we simulated 50 temporally matched pseudo-absences (controls) representing accessible areas where animals could potentially have travelled (see e.g. Wakefield et al. 2011, Žydelis et al. 2011, Raymond et al. 2015). These were created using correlated random walks (CRWs), based on the distribution of observed turning angles and distances between successive locations, using the adehabitatLT package (Calenge 2006). A constraint function defined by the minimum convex polygon (MCP) of all observed locations, increased by a $200 \mathrm{~km}$ buffer to account for GLS logger error, was used to restrict the CRWs (Žydelis et al. 2011). The number of simulated 
locations was determined by measuring changes in $\chi^{2}$ values of each parameter by running global models with all observed locations and varying numbers of simulated pseudo-absences (Žydelis et al. 2011). Fifty CRWs were sufficient for most parameters, even though a few would have ideally required even more CRWs. However, and given the computational requirements associated with large numbers of CRWs, we used 50 for all our models (see Fig. S1 in the Supplement at www.int-res.com/articles/suppl/m553 p267_supp.pdf).

A set of oceanographic variables were included as candidate predictors in the habitat models on the basis of their biological relevance, i.e. their potential influence on skua distribution. To account for geolocation error, a buffer of $200 \mathrm{~km}$ was created around each observed and simulated location. A spatially weighted average of all oceanographic data was calculated for each of those locations. Potential predictors were: (1) depth (a proxy for coastal or pelagic domains), extracted from ETOPO1 at a spatial resolution of $0.01^{\circ}$, downloaded from https://www. ngdc.noaa.gov/mgg/global/global.html, and, for 2002 and 2012, (2) chlorophyll a ( $\mathrm{chl} a$, a surrogate of marine productivity), $8 \mathrm{~d}$ composites derived from SeaWIFS and Aqua MODIS, respectively, with a $0.09^{\circ}$ spatial resolution, (3) sea surface temperature (SST, a proxy for water mass), a product from NOAA Pathfinder Advanced Very High Resolution Radiometer (AVHRR) v. 5.2, at $0.04^{\circ}$ spatial and daily temporal resolutions, (4) eddy kinetic energy (EKE) and (5) sea level anomaly (SLA), which are indices of mesoscale activity and were daily delayed time AVISO DUACS products with a $0.3^{\circ}$ spatial resolution. All remotely sensed variables were extracted using the Marine Geospatial Ecology Tools (MGET) for ArcGIS v. 10.2.2 (Roberts et al. 2010). As the volume of missing data prevented the use of daily composites, an average of three $8 \mathrm{~d}$ or twenty-four $1 \mathrm{~d}$ composites centred on the date of the location was created for the dynamic predictors. After creating the composites, values for chl a were still missing for $\sim 24 \%$ of locations. Such a large proportion is likely to affect inference because of the systematic pattern in the occurrence of missing values (Wakefield et al. 2011); therefore, chl a was discarded as a predictor in the analyses. All composites were created from customized functions and the raster package in R. Additionally, spatial gradients of SST (SST gradient, an indicator of the presence of frontal systems) and depth (depth slope, a proxy for topographic features) were calculated as the standard deviation of the mean.
Prior to GAM analysis, predictors were tested for colinearity by calculating all pairwise Spearman rank correlations $\left(\mathrm{r}_{\mathrm{S}}\right)$ and when $\left|\mathrm{r}_{\mathrm{S}}\right|>0.5$, predictors were not included in the same model. Habitat selection was examined using GAMs because data exploration indicated potentially non-linear relationships between response and predictors. GAMs take into account non-linear relationships using non-parametric smoothers to fit flexible curves to data (Aarts et al. 2008) and were implemented within the mgcv package (Wood 2006). Smooth functions for model predictors were specified using cubic regression splines with shrinkage to avoid overparameterization and to identify the most parsimonious number of knots (Wood 2006). The number of knots (k), representing maximum degrees of freedom of each smooth, was manually limited by $k=4$ to avoid excessive flexibility and model overfitting that would have no ecological meaning (Mannocci et al. 2014). Due to the dynamic nature of oceanographic predictors and possible changes in habitat preferences, year, but not sex or breeding status, was included as an interaction in the models.

The best minimum models were determined by forward selection using $k$-fold cross-validation (Wakefield et al. 2011), testing the goodness of fit of each individual, in turn, against the prediction based on the other 24 individuals. Cross-validation was preferred over information criteria, e.g. the Akaike information criterion (AIC), as the latter can lead to overparameterized models because of violation of the independence assumption inherent within tracking datasets (Aarts et al. 2008, Cleasby et al. 2015). Cross-validation prevents overparameterization by using a set of data for fitting the model and another set for assessing predictive performance (Aarts et al. 2008). Each model was trained on 24 folds and tested, in turn, on the remaining, withheld fold which represented an individual. Model selection was based on the predictive ability of the model using the area under the receiver operating curve (AUC) averaged across the 25 sets of results (i.e. individuals) using the pROC package (see Raymond et al. 2015). AUC values between 0.5 and 0.7 indicate poor model predictive ability, values from 0.7 to 0.9 indicate reasonable model discrimination ability, and values higher than 0.9 indicate very good model discrimination (Pearce \& Ferrier 2000). The forward selection procedure consisted initially of fitting all possible single predictor models with and without the year-interaction and ranking those models according to AUC. The best ranking model was chosen, and then, each of the remaining predictors was added in turn; the best 
model among this new set was then retained if the AUC increased significantly. This process was continued until there was no further increase in the AUC. The significance of the increase in AUC between 2 models was tested with a paired $t$-test. Using cross-validation and paired $t$-tests to compare AUCs is somewhat conservative; however, we considered this approach to be the best solution to avoid overparameterization, as it prevents adding parameters that only contribute trivially to increasing AUC. Habitat preference models were fitted separately for the nonbreeding and pre-laying periods.

Timing (departure and return dates, and duration), the size of the core and general use areas (40 and $95 \%$ UDs), travel speeds and distances (summed great circle distances between the locations) were compared between birds of different sex and breeding status during the pre-laying exodus and migration periods. The effect of year was included in models for the migration but not pre-laying period because of the reduced sample size (only 2 birds engaged in a pre-laying exodus in 2002). All main effects and interactions were tested in linear models. AIC values were used to rank all possible models according to their degree of parsimony; the best model was the one with the lowest AIC. If 2 or more models were within 2 AIC units from the best-supported model, differed by one parameter and had a similar maximized log-likelihood value, only the most parsimonious model was selected. The latter suggests that improvements in model fit have not been enough to overcome the penalty of an additional parameter (Burnham \& Anderson 2002, Arnold 2010). Unless indicated otherwise, all data are presented as mean $\pm \mathrm{SD}$.

The combined GLS-immersion loggers tested for saltwater immersion every $3 \mathrm{~s}$. The number of positive tests was recorded for each 10 min period, providing a value that ranged from 0 (continuously dry) to 200 (continuously wet). Each 10 min period was categorised as daylight or darkness using sunset and sunrise times estimated from the thresholds in light curves recorded by the same loggers. The activity data were used to determine the daily proportion of time spent flying during daylight and darkness (each consecutive light and dark period), as well as the total time spent per day in flight and on water. The duration and number of flight bouts per day were also calculated. A flight bout was defined as any continuous sequence of 10 min periods of completely dry (0) values. This method is likely to underestimate the number of flight bouts, as birds may engage in multiple short periods of flight within $10 \mathrm{~min}$. However,
Phalan et al. (2007) found a close correlation between bouts derived from lower and higher resolution loggers (which record immersion every $10 \mathrm{~s}$ ), indicating that bouts are adequate as proxies of activity. Atsea activity characteristics were compared between sexes and between daylight vs. darkness using linear mixed-effect models with individual identity included as a random effect. Year was not included in the models because of the limited sample size for 2001/ 2002 (only 3 birds for the non-breeding period and 2 birds for the pre-laying exodus). Proportion data were arcsine transformed. Models including all combinations of variables as well as their interactions were tested using AIC values following the approach described above.

\section{RESULTS}

Eight out of 28 breeding adults (29\%) fitted with loggers in summer 2001/2002 returned to breed in 2002; 7 loggers were retrieved (1 bird was not recaptured), of which 1 failed to download. Immersion data were only available for 3 of the loggers. The low return rate of instrumented birds was attributed to the accretion of goose barnacles Lepas spp. to the self-amalgamating tape wrapped around the logger, causing an increase in load on the leg, and is discussed in Phillips et al. (2007). Of 25 birds fitted with a logger in 2011/2012, 22 returned to breed in the following season, from which 19 loggers were retrieved (3 loggers were lost). Return rates were higher for birds with devices (22 of $25 ; 88 \%$ ) than for control birds (60 of $82 ; 73 \%$ ), all fitted with a plastic colourring with a unique alpha-numeric sequence in the first season, but the difference was not statistically significant (Fisher's exact test, $\mathrm{p}=0.18$ ).

\section{Non-breeding period}

Tracked skuas started their outward migration on 4 March \pm 19 d (range: 3 February to 22 April, $n=24$ ) . There was no significant effect of year on mean departure date (Table 1), but birds returned to South Georgia ca. $10 \mathrm{~d}$ earlier in 2002, on 5 October $\pm 8 \mathrm{~d}$ (range: 30 September to 15 October, $\mathrm{n}=3$ ), compared with 16 October $\pm 10 \mathrm{~d}$ (range: 26 September to 4 November, $\mathrm{n}=19$ ) in 2012. The migration period lasted ca. $225 \pm 20$ d (range: 192 to $270, n=22$ ) and was similar between years (Table 1). Departure dates and durations of the migration period, but not return dates, varied according to breeding status and sex 

ary and only started its outward migration on 4 April, failed birds departed earlier than birds that bred successfully, on 21 February $\pm 16 \mathrm{~d}$ (range: 3 February to 31 March, $\mathrm{n}=12$ ) and 16 March $\pm 15 \mathrm{~d}$ (range: 1 March to 22 April, $\mathrm{n}=12$ ), respectively (Table 1). Males departed 3 to $4 \mathrm{wk}$ later than females, on 17 March $\pm 18 \mathrm{~d}$ (range: 19 February to 22 April, $\mathrm{n}=10$ ), compared with 23 February \pm 14 d (range: 3 February to 22 March, $\mathrm{n}=15$; Table 1 ); however, the effect of sex probably only reflects differences associated with breeding status, as the proportion of tracked males that bred successfully was higher than the proportion of females (60 vs. $40 \%$ ). The mean distance travelled during migration was $391.9 \pm 71.6 \mathrm{~km} \mathrm{~d}^{-1}$ (range: 272.9 to $540.2 \mathrm{~km}, \mathrm{n}=24$ ), with no effect of year, sex or breeding status (Table 1). Maximum distances from the colony varied according to breeding status, ranging from 1824 to $5066 \mathrm{~km}(3009 \pm 1043$, $\mathrm{n}=13$ ) for failed birds, and from 1445 to $3363 \mathrm{~km}$ $(2400 \pm 489 \mathrm{~km}, \mathrm{n}=11)$ for successful birds. There was no difference in the maximum distance travelled from the colony between 2002 and 2012, nor between males and females (Table 1).

Skuas were distributed over a wide area $(95 \%$ UDs) during the non-breeding period, ranging from 2437500 to $9455000 \mathrm{~km}^{2}\left(4442500 \pm 1470068 \mathrm{~km}^{2}\right.$,
(Table 1). Excluding 1 bird that failed in early Febru-

$\mathrm{n}=24 ;$ Fig. 1). The distribution was limited to waters between the northern extent of the Subtropical Front and the southern boundary of the Antarctic Circumpolar Current, and between the Argentine and Agulhas basins. Core areas were $717396 \pm 244662 \mathrm{~km}^{2}$ (range: 370000 to $1597500 \mathrm{~km}^{2}, \mathrm{n}=24$; Fig. 1). Although the non-breeding range appeared to be more extensive in 2012 than 2002, there was no significant effect of year, sex or breeding status on distribution according to the results of the ANOSIM $(\mathrm{R}=$ $0.0-0.1, p>0.05)$, nor did these factors affect the size of individual 95 and $40 \%$ UDs (Table 1).

The best model predicting skua distribution from oceanographic variables during the non-breeding period achieved an accuracy of AUC $=0.76$ (reasonable discrimination ability). However, the predictive accuracy when calculated separately for each individual varied from $\mathrm{AUC}=0.50$ (no discrimination) to $\mathrm{AUC}=$ 0.91 (very good discrimination). The most important predictors of habitat use by the tracked skuas were, in order of decreasing importance, depth and depth slope. Model response curves indicated that probability of occurrence was higher in both shallow and deep water (i.e. lowest in mid-depths), and in areas with steeper depth slopes (Fig. 2). There was no effect of year on habitat preference during the non-breeding period, nor did the tracked birds prefer areas according to SST, SST gradient, EKE or SLA.

Table 1. Linear models for the effects of sex, breeding status (successful or failed) and year on characteristics of the non-breeding period and pre-laying exodus of brown skuas tracked from South Georgia in winter 2002 and 2012. Only the most parsimonious models are shown. +: predictors that were retained by the most parsimonious models; na: not applicable, i.e. predictors that were not included in the analysis. Interactions are not shown because they were not retained in the best models. AICc: Akaike information criterion corrected for small sample sizes; Max.: maximum; UD: utilization distribution

\begin{tabular}{|c|c|c|c|c|c|}
\hline & Sex & Status & Year & df & $\mathrm{AICc}$ \\
\hline \multicolumn{6}{|l|}{ Non-breeding period } \\
\hline Departure dates & + & + & & 4 & 193.6 \\
\hline Return dates & & & + & 3 & 169.2 \\
\hline Duration & + & + & & 4 & 175.3 \\
\hline Size of core area ( $40 \%$ UD) & & & & 2 & 667.2 \\
\hline Size of general use area (95\% UD) & & & & 2 & 753.3 \\
\hline Distance travelled $\mathrm{d}^{-1}$ & & & & 2 & -11.7 \\
\hline Max. distance from colony & & + & & 3 & 10.8 \\
\hline \multicolumn{6}{|l|}{ Pre-laying exodus } \\
\hline Departure dates & & & na & 2 & -46.6 \\
\hline Return dates & & & na & 2 & 90.6 \\
\hline Duration & & & na & 2 & 38.0 \\
\hline Size of core area ( $40 \%$ UD) & & & na & 2 & 1.6 \\
\hline Size of general use area (95\% UD) & & & na & 2 & 1.3 \\
\hline Distance travelled $\mathrm{d}^{-1}$ & & & na & 2 & 19.1 \\
\hline Max. distance from colony & & & na & 2 & 85.5 \\
\hline
\end{tabular}

\section{Pre-laying exodus}

After the return to South Georgia, 2 out of $3(67 \%)$ and 10 out of $19(53 \%)$ brown skuas that returned to breed in 2002 and 2012, respectively, engaged in a pre-laying exodus. No characteristic of the pre-laying exodus (start and return dates, duration, distance travelled per day and maximum range from the colony) differed significantly between males and females, nor between birds that bred successfully or failed in the previous season (Table 1). However, the majority ( $75 \%$ ) of pre-laying trips were performed by females. Skuas departed to sea on 30 October $\pm 9 \mathrm{~d}$ (range: 18 October to 15 November, $\mathrm{n}=12$ ), which was $16 \pm 8 d$ (range: 8 to $39 d, n=12$ ) after their first return to the colony, for a pre-laying exodus that lasted 6 to $9 \mathrm{~d}(7 \pm 1 \mathrm{~d}, \mathrm{n}=$ 12). All trips were to the north of South Georgia, ranging from 772 to $2636 \mathrm{~km}$ from the colony $(1553 \pm 580 \mathrm{~km}, \mathrm{n}=12)$. Trips 

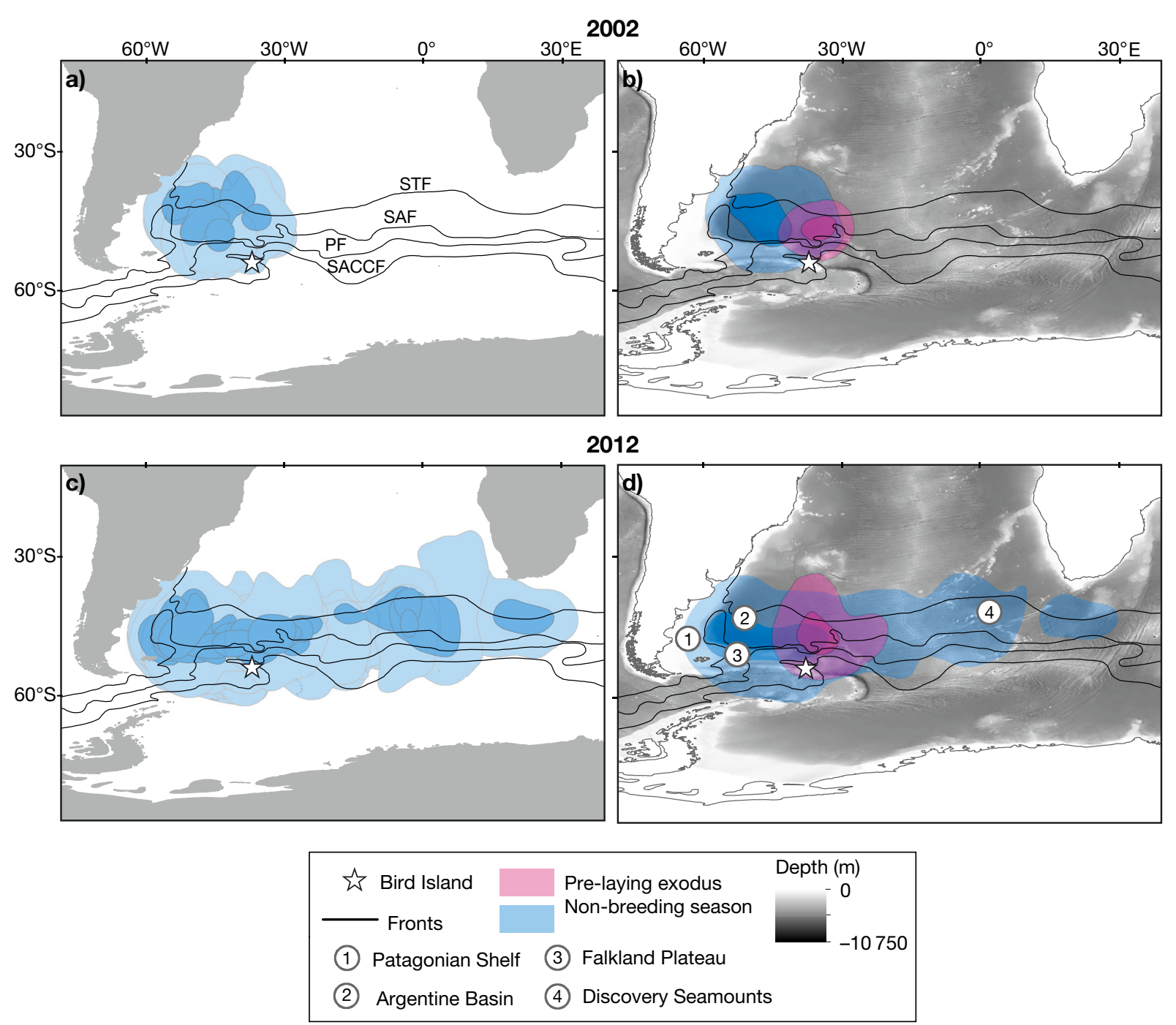

Fig. 1. Utilization distributions (40\% [dark] and $95 \%$ [light]) of individual brown skuas Stercorarius antarcticus tracked from South Georgia during the non-breeding season in (a) 2002 and (c) 2012. Composite of individual utilization distributions (40 and $95 \%$ ) during non-breeding and pre-laying exodus in (b) 2002 and (d) 2012 overlaid on bathymetric map. Black lines correspond to STF (Subtropical Front), SAF (Subantarctic Front), PF (Polar Front), and SACCF (Southern Antarctic Circumpolar Current Front)

were to subantarctic and mixed subantarctic-subtropical waters (Fig. 1). The tracked birds covered $455 \pm 212 \mathrm{~km} \mathrm{~d}^{-1}$ (range: 195.5 to $953 \mathrm{~km} \mathrm{~d}^{-1}, \mathrm{n}=12$ ). Individual core areas and $95 \%$ UDs during the prelaying exodus ranged from 195000 to $402500 \mathrm{~km}^{2}$ (256250 $\left.\pm 61158 \mathrm{~km}^{2}, \mathrm{n}=12\right)$ and from 1105000 to $2360000 \mathrm{~km}^{2}\left(1538333 \pm 345694 \mathrm{~km}^{2}, \mathrm{n}=12\right)$, respectively. There were no significant effects of sex or breeding status on distributions (ANOSIM results, $\mathrm{R}=-0.1-0.2, \mathrm{p}>0.05)$, nor on the size of individual core and general use areas according to linear models (Table 1).

Depth was the main predictor of skua distribution during the pre-laying period. The best model had reasonable discrimination ability (AUC $=0.77$ ). Variation among individuals, however, was considerable, with predictive accuracies ranging from none (AUC = 0.50 ) to very high (AUC $=0.93$ ). Probability of occurrence of brown skuas increased in areas with greater water depth (Fig. 3). Habitat selection by tracked skuas was not affected by year, SST, SST gradient, EKE, SLA, and depth slope.

\section{At-sea activity patterns}

Given the few birds sampled in 2002, immersion data from both years were pooled. Brown skuas 

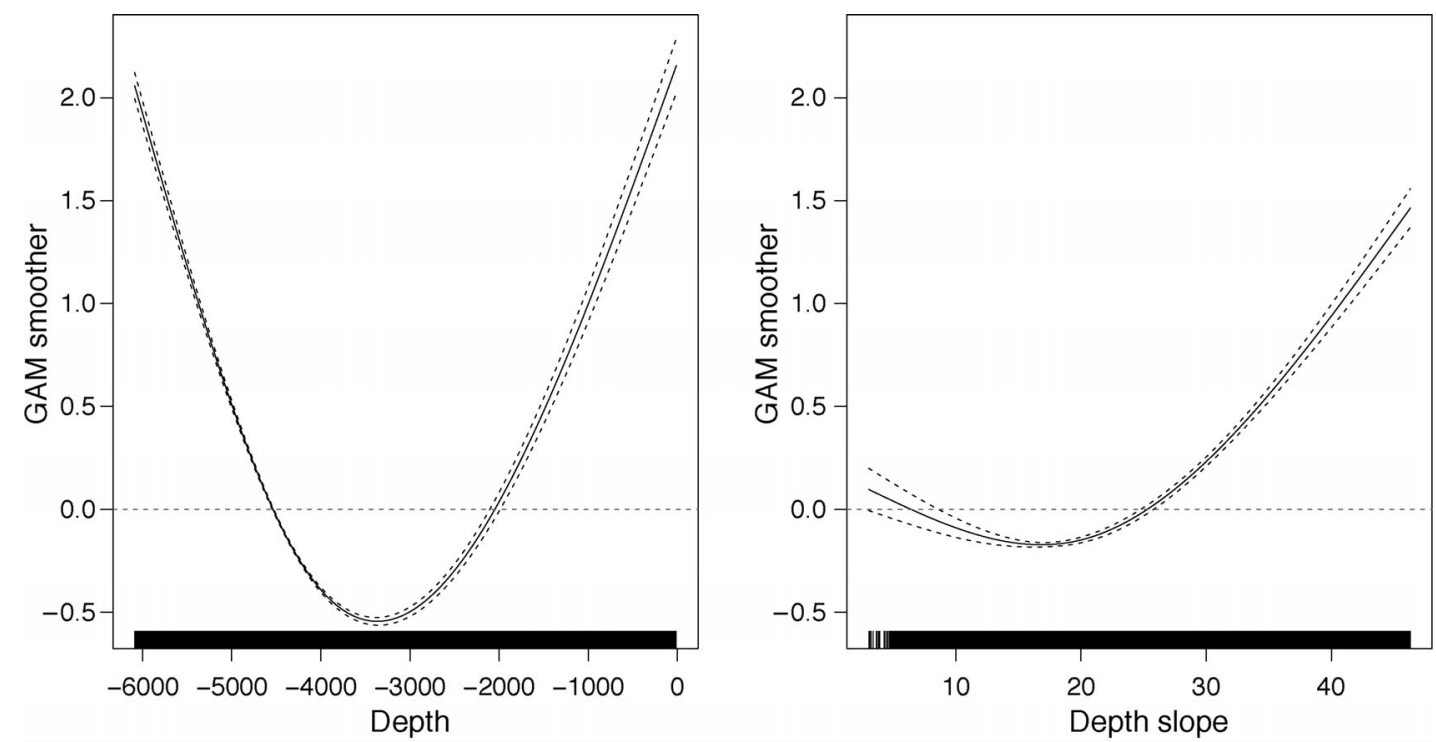

Fig. 2. Response curves of predictors retained in the most parsimonious habitat model for brown skuas during the non-breeding period. Dashed lines indicate estimated $95 \%$ confidence intervals, with covariate values as a rug along the bottom of the figure

from South Georgia spent a considerably smaller percentage of time in flight than on the water during both the non-breeding and pre-laying exodus periods (Tables 2 \& 3). During the non-breeding period, females spent more time than males in flight during darkness, probably as a consequence of longer, but not more frequent, flight bouts (Tables 2

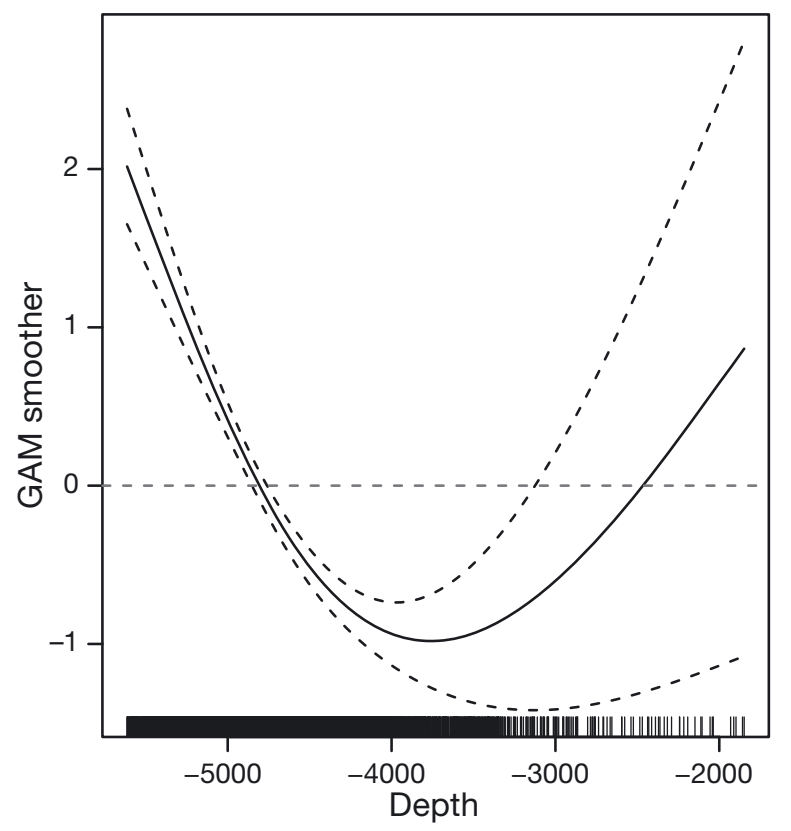

Fig. 3. Response curves of predictors retained in the most parsimonious habitat model for brown skuas during the prelaying exodus. Dashed lines indicate estimated 95\% confidence intervals, with covariate values as a rug along the bottom of the figure
\& 3). Skuas were more active (i.e. performed more flight bouts), during daylight than darkness; however, the bouts in daylight were shorter. During the pre-laying exodus, although the proportion of time spent in flight appeared to be higher in daylight than darkness, this was not reflected in the best model, nor in this case, was there a significant difference between males and females (Tables $2 \& 3$ ). Flight bout duration, however, was longer during darkness, and females engaged in more flight bouts per day than males. There was no difference in the number of flight bouts per day between daylight and darkness, nor in the duration of flight bouts between males and females during the pre-laying exodus (Tables $2 \& 3$ ).

\section{DISCUSSION}

\section{Distribution and habitat use}

With the inclusion of the new, large sample from 2012, this study represents the most detailed published analysis of movements and activity patterns of brown skuas during the non-breeding and prelaying exodus periods. Although habitat use of brown skuas was described previously in terms of differences in bathymetry, sea surface temperature and chl a concentrations between core and peripheral areas (Phillips et al. 2007), this is the first study to present a robust model of habitat preference, accounting for availability. The loggers deployed in 
Table 2. Activity patterns of brown skuas tracked from South Georgia during the non-breeding period and pre-laying exodus in winter 2002 and 2012. Values presented as mean \pm SD (range)

\begin{tabular}{|c|c|c|c|c|}
\hline \multirow[t]{2}{*}{ Year } & \multicolumn{2}{|c|}{-Daylight } & \multicolumn{2}{|c|}{ Darkness } \\
\hline & Male & Female & Male & Female \\
\hline \multicolumn{5}{|c|}{ Non-breeding period } \\
\hline \multicolumn{5}{|c|}{ Time in flight (\%) } \\
\hline 2002 & $25.9 \pm 0.0(25.9-25.9)$ & $19.8 \pm 6.9(14.9-24.7)$ & $11.4 \pm 0.0(11.4-11.4)$ & $15.1 \pm 1.4(14.1-16.1)$ \\
\hline 2012 & $24.8 \pm 4.5(18.8-33.0)$ & $25.9 \pm 5.4(17.9-37.5)$ & $16.9 \pm 3.9(12.1-22.7)$ & $24.5 \pm 7.9(9.2-42.0)$ \\
\hline \multicolumn{5}{|c|}{ Total time in flight $\left(\mathrm{h} \mathrm{d}^{-1}\right)$} \\
\hline 2002 & $3.0 \pm 0.0(3.0-3.0)$ & $2.3 \pm 0.8(1.7-2.9)$ & $1.4 \pm 0.0(1.4-1.4)$ & $1.9 \pm 0.2(1.8-2.1)$ \\
\hline 2012 & $2.6 \pm 0.5(2.0-3.5)$ & $2.9 \pm 0.7(1.9-4.1)$ & $2.2 \pm 0.5(1.6-3.1)$ & $3.2 \pm 1.1(1.2-5.6)$ \\
\hline \multicolumn{5}{|c|}{ Total time on water $\left(\mathrm{h} \mathrm{d}^{-1}\right)$} \\
\hline 2002 & $8.5 \pm 0.0(8.5-8.5)$ & $9.3 \pm 0.8(8.7-9.9)$ & $11 \pm 0.0(11.0-11.0)$ & $10.5 \pm 0.2(10.4-10.6)$ \\
\hline 2012 & $8.0 \pm 0.5(7.2-8.6)$ & $8.3 \pm 0.8(6.9-9.5)$ & $11.2 \pm 0.5(10.6-11.7)$ & $9.7 \pm 1.2(7.7-11.7)$ \\
\hline \multicolumn{5}{|c|}{ No. of flight bouts $\mathrm{d}^{-1}$} \\
\hline 2002 & $2.3 \pm 0.0(2.3-2.3)$ & $2.0 \pm 1.0(1.3-2.7)$ & $0.9 \pm 0.0(0.9-0.9)$ & $1.3 \pm 0.1(1.2-1.4)$ \\
\hline 2012 & $1.8 \pm 0.8(0.9-2.7)$ & $2.2 \pm 0.7(1.0-3.7)$ & $1.3 \pm 0.3(1.0-1.9)$ & $1.4 \pm 0.4(0.9-2.0)$ \\
\hline \multicolumn{5}{|c|}{ Duration of flight bouts (min) } \\
\hline 2002 & $29.1 \pm 0.0(29.1-29.1)$ & $32.9 \pm 4.4(29.8-36.0)$ & $85.9 \pm 0.0(85.9-85.9)$ & $89.7 \pm 1.5(88.7-90.8)$ \\
\hline 2012 & $30.8 \pm 2.2(28.6-35.1)$ & $46.1 \pm 29.3(33.4-135.7)$ & $95.6 \pm 15.4(81.6-119.3)$ & $119.7 \pm 43.7(57.6-188.9)$ \\
\hline \multicolumn{5}{|c|}{ Pre-laying exodus } \\
\hline \multicolumn{5}{|c|}{ Time in flight $(\%)$} \\
\hline 2002 & $23.4 \pm 0.0(23.4-23.4)$ & $11.5 \pm 0.0(11.5-11.5)$ & $1.4 \pm 0.0(1.4-1.4)$ & $0.3 \pm 0.0(0.3-0.3)$ \\
\hline 2012 & $13.6 \pm 3.3(11.3-15.9)$ & $19.1 \pm 9.0(12.6-40.0)$ & $9.9 \pm 6.1(5.6-14.2)$ & $17.8 \pm 10.0(5.2-33.0)$ \\
\hline \multicolumn{5}{|c|}{ Total time in flight $\left(\mathrm{h} \mathrm{d}^{-1}\right)$} \\
\hline 2002 & $3.6 \pm 0.0(3.6-3.6)$ & $1.7 \pm 0.0(1.7-1.7)$ & $0.2 \pm 0.0(0.2-0.2)$ & $0.0 \pm 0.0(0.0-0.0)$ \\
\hline 2012 & $2.0 \pm 0.4(1.7-2.3)$ & $2.6 \pm 1.4(1.1-5.6)$ & $0.9 \pm 0.6(0.5-1.3)$ & $1.9 \pm 1.2(0.4-4.0)$ \\
\hline \multicolumn{5}{|c|}{ Total time on water $\left(\mathrm{h} \mathrm{d}^{-1}\right)$} \\
\hline 2002 & $12.0 \pm 0.0(12.0-12.0)$ & $13.6 \pm 0.0(13.6-13.6)$ & $8.1 \pm 0.0(8.1-8.1)$ & $8.6 \pm 0.0(8.6-8.6)$ \\
\hline 2012 & $12.4 \pm 0.7(11.9-12.9)$ & $10.6 \pm 2.2(7.9-13.5)$ & $8.6 \pm 0.8(8.1-9.1)$ & $8.8 \pm 2.4(6.1-13.0)$ \\
\hline \multicolumn{5}{|c|}{ No. of flight bouts $\mathrm{d}^{-1}$} \\
\hline 2002 & $2.0 \pm 0.0(2.0-2.0)$ & $1.1 \pm 0.0(1.1-1.1)$ & $0.5 \pm 0.0(0.5-0.5)$ & $0.1 \pm 0.0(0.1-0.1)$ \\
\hline 2012 & $0.5 \pm 0.2(0.3-0.7)$ & $2.0 \pm 1.9(0.7-6.1)$ & $0.8 \pm 0.2(0.7-1.0)$ & $1.4 \pm 1.0(0.3-3.4)$ \\
\hline \multicolumn{5}{|c|}{ Duration of flight bouts (min) } \\
\hline 2002 & $46.0 \pm 0.0(46.0-46.0)$ & $34.4 \pm 0.0(34.4-34.4)$ & $63.3 \pm 0.0(63.3-63.3)$ & $28.2 \pm 0.0(28.2-28.2)$ \\
\hline 2012 & $23.7 \pm 2.7(21.8-25.6)$ & $40.5 \pm 18.4(26.1-77.5)$ & $62.3 \pm 6.8(57.5-67.1)$ & $67.5 \pm 40.8(24.9-147.2)$ \\
\hline
\end{tabular}

summer 2011/2012 had no deleterious effect on adult survival; indeed, return rates were higher, but not statistically significant, for birds with devices than for control birds. Although some birds in the larger sample tracked in winter 2012 travelled to areas east of those used in winter 2002, there were no statistically significant differences in distribution, the size of the core and general use areas, nor in habitat preferences, despite the decade that had elapsed between the 2 series of deployments. Similarly, northern hemisphere skuas (great Stercorarius skua and longtailed S. longicaudus skuas) tracked during 2 or 3 consecutive years migrated to the same general regions and had similar migration schedules (Sittler et al. 2011, Magnusdottir et al. 2012, Gilg et al. 2013).

Table 3. Summary of linear mixed-effects models of activity patterns of brown skuas tracked from South Georgia in 2002 and 2012 during the non-breeding period and pre-laying exodus. Only the most parsimonious models are shown. +: predictors retained in the most parsimonious models. AICc: Akaike information criterion corrected for small sample sizes

\begin{tabular}{|c|c|c|c|c|c|}
\hline Dayl & vs. darkness & Sex & LightDark:Sex & $\mathrm{df}$ & $\mathrm{AICc}$ \\
\hline \multicolumn{6}{|l|}{ Non-breeding period } \\
\hline Time in flight (\%) & + & + & + & 6 & -1399.6 \\
\hline No. of flight bouts $\mathrm{d}^{-1}$ & + & & & 3 & -3.7 \\
\hline Duration of flight bouts & + & + & & 4 & 373.1 \\
\hline \multicolumn{6}{|l|}{ Pre-laying exodus } \\
\hline Time in flight $(\%)$ & & & & 3 & -82.9 \\
\hline No. of flight bouts $\mathrm{d}^{-1}$ & & + & & 3 & 50.0 \\
\hline Duration of flight bouts & + & & & 3 & 32.0 \\
\hline
\end{tabular}


The brown skuas tracked in this study were not limited to any specific water mass; however, most of their core areas were in subantarctic and mixed subantarctic subtropical waters during both the nonbreeding season and the pre-laying exodus. They preferred regions with either shallow or deep waters, and increasing depth slopes, during the migration period, whereas in the pre-laying exodus, they selected habitat based solely on water depth. This confirms the inference from stable isotope analysis that a minority of brown skuas winter in shelf-slope waters (Phillips et al. 2007, 2009). Depth gradients are steeper at seamounts and where shelf-edge fronts form, which are zones of intense mixing and enhanced primary production (Bost et al. 2009, Louzao et al. 2011b, Wakefield et al. 2011, Scales et al. 2014). Also, several studies have shown associations of seabirds with frontal systems influenced by bathymetric features (Phillips et al. 2005, 2006, Paiva et al. 2010a,b, Louzao et al. 2011b, Rayner et al. 2012).

In the present study, the core areas of several individuals (as well as the composite $40 \%$ UDs for the population) overlapped extensively with regions of steeper slopes around the Falkland Escarpment, which forms the boundary between the Falkland Plateau and the Argentine Basin (Fig. 1). The Falkland Escarpment is a region subject to high frontal probability during the austral autumn, winter and spring, mostly associated with the presence of eddies from the Brazil-Malvinas Confluence, where the warm Brazil Current and the cold Malvinas Current meet (Saraceno et al. 2004). Moreover, 5 birds targeted areas of shallower bathymetry around the Discovery Rise and its associated seamounts during their migration in 2012, whilst one bird travelled as far as the Agulhas Basin, reaching turbulence zones from the Agulhas Return Current, where primary productivity is enhanced.

Although the skuas showed a preference for oceanographic characteristics that are often found in areas with abundant and predictable prey, it is noteworthy that much of the Argentine Basin, which was one of the main wintering areas, is not particularly productive based on chl a concentrations (Phillips et al. 2007). This suggests that bathymetric features alone cannot entirely explain the observed distribution of brown skuas. Quillfeldt et al. (2013) suggested that Antarctic prions Pachyptila desolata may occur in deep waters to the east of the Patagonian Shelf in order to avoid competition with larger seabirds. The same may be true for brown skuas, as the Patagonian Shelf is used year-round by numerous albatross and petrel populations from Tristan da Cunha, Gough, the Falkland Islands, South Georgia, and New Zealand (Croxall \& Wood 2002, Phillips et al. 2006, Catry et al. 2013b, Copello et al. 2013). The ranges of the tracked brown skuas still overlapped to some extent with non-breeding Falkland skuas $S$. antarcticus antarcticus (Phillips et al. 2007), and even more with wandering albatrosses Diomedea exulans, yearround (Jiménez et al. 2016). However, inter-specific competition between these taxa may be alleviated by trophic partitioning of resources or differences in behaviour. Whilst $\delta^{13} \mathrm{C}$ values are similar for wandering albatrosses and brown skuas, $\delta^{15} \mathrm{~N}$ values in feathers from wandering albatrosses are much higher, and their activity patterns differ (Phalan et al. 2007, 2009, Ceia et al. 2012). Therefore, although the tracking and isotope data indicate that they occur in the same general area, wandering albatrosses feed at substantially higher trophic levels. Although $\delta^{15} \mathrm{~N}$ values in brown skuas are significantly higher than in nonbreeding Antarctic prions, this is not by a full trophic level, suggesting there is some diet overlap (Phillips et al. 2007, 2009). Antarctic prions feed on a wider range of small zooplankton taxa, whereas brown skuas probably have a mixed diet that includes zooplankton, low trophic level squid or fish (Phillips et al. 2007, Grecian et al. 2015). Finally, skuas breeding at the Falkland Islands occur closer to the Patagonian shelf-break and to a lesser extent in open waters than brown skuas (Phillips et al. 2007).

As brown skuas select habitats based mainly on static oceanography (water depth), their return to the same general area each year is not surprising, assuming that prey preferences are also consistent. Similarly, the use of neritic waters and areas of steeper bathymetric relief by black-browed albatrosses varied very little over multiple breeding seasons (Pinaud \& Weimerskirch 2005, Wakefield et al. 2011, Catry et al. 2013b). The recurrent use of similar areas may increase familiarity with feeding conditions, including fine-scale resource distribution, and potentially help reduce inter-specific competition (Quillfeldt et al. 2013, Ramírez et al. 2015). Although habitat preferences were consistent between years, the tracked skuas had multiple migration destinations in 2012, which should ensure that a proportion of the population would escape from detrimental changes during winter if those are constrained spatially (Phillips et al. 2009, Dias et al. 2011). At the population level, core and general use areas did not differ significantly between years, but a few individuals in 2012 travelled to regions east of those exploited in 2002 (Fig. 1). Two birds in this latter group remained ex- 
clusively in the Agulhas Basin or in waters around the Discovery Rise, whereas another 4 birds used areas around the Discovery Rise and in the Argentine Basin. The existence of several non-breeding destinations for the same population has been confirmed for many seabird species, including south polar and great skuas (Phillips et al. 2005, Dias et al. 2011, Kopp et al. 2011, Magnusdottir et al. 2012, McFarlane Tranquilla et al. 2013, Ramírez et al. 2015). That the minority strategies were not detected in brown skuas from South Georgia in the first set of deployments probably reflects the modest sample size rather than indicates that birds have explored new environments in the subsequent decade. This is supported by the stable isotope data which suggests that some birds sampled in 2001/2002 had exploited neritic or shelf-slope waters in the previous winter (see above) and by the lack of any substantial differences between years in distribution based on randomizations, or in habitat preferences (present study). Regardless, the 2 tracking datasets provide an adequate representation of the distribution of the majority of individuals. Indeed, in an analysis of $15 \mathrm{yr}$ of tracking data, Bogdanova et al. (2014) suggested that 1 or $2 \mathrm{yr}$ of data is usually sufficient to identify a considerable proportion of the long-term foraging areas for species which feed in spatially stable habitats. Furthermore, the distributions of general (95\% UD) and core areas $(40 \%)$ of the tracked skuas were not influenced by sex or breeding status, which are complicating factors in other studies (Bogdanova et al. 2011, 2014).

\section{Migration schedules}

Failed birds departed from the breeding grounds earlier than successful birds, in line with other studies (Phillips et al. 2005, Bogdanova et al. 2011, Quillfeldt et al. 2015). If migration commences earlier, more time may be allocated to undertake farther movements. Indeed, maximum distance from the colony was higher for failed than for successful breeders. Failed birds may also be in better condition to undertake longer migrations, as costs associated with breeding have been lower (Bogdanova et al. 2011). The latter is particularly likely for skuas at South Georgia, which are able to exploit abundant seal carrion only in December and January; thereafter, the availability of carrion declines steeply and breeding birds are forced to target other, less profitable prey (Phillips et al. 2004a, Anderson et al. 2009, Carneiro et al. 2014). Therefore, a movement away from the breeding grounds to areas with more favourable conditions should be expected for failed birds that are no longer under central-place constraints.

The mean date of return to South Georgia, however, was similar for all tracked individuals within the same year, suggesting that previous breeding outcome ceased to be important at some stage during the migration period (Phillips et al. 2005). Similar arrival dates may decrease the chances of nest site usurpation by prospectors seeking to adopt a vacant site (Furness 1987). Indeed, it has been suggested that nesting habitat in the study area is saturated, with few opportunities for the establishment of new territories (Phillips et al. 2004a). The explanation for the later return of tracked birds to the colony in 2012 than 2002 is less clear. Shifts in phenology are expected as a response to climate change, and in the Southern Ocean, dates of arrival and of the first egg have been later for a number of species (Barbraud \& Weimerskirch 2006). In summer 2002/2003, brown skuas at South Georgia laid later and had lower hatching success, fledging success and chick growth rates than in the mid-1980s (Phillips et al. 2004a). Later arrival in 2012 than 2002 may, therefore, be indicative of poorer environmental conditions during the preceding winter, potentially reflecting a longerterm trend, but this would need to be confirmed by more extensive tracking. There was no consistent effect of sex on timing of movements, in accordance with previous studies of arrival times of brown skuas at the South Orkney Islands and of migration schedules of long-tailed skuas in the high Arctic (Burton 1968, Gilg et al. 2013).

Prior to egg-laying and after returning from migration, ca. $55 \%$ of tracked skuas travelled to waters to the north of South Georgia in a pre-laying exodus. Although timings and distances travelled were unaffected by sex and previous breeding status, a prelaying exodus was more commonly performed by females. At this time of year, food resources accessible on land for skuas are likely to be limited. There is very little carrion available from seals, and most burrow-nesting petrels have yet to return (Carneiro et al. 2014). Skuas arrive earlier at their breeding grounds to defend their territories and (re)establish pair bonds, but it is possible that to acquire enough resources for egg formation, females have to return to feed at sea. In most seabird species, females are generally away for longer periods or travel farther to reach more productive waters (Guilford et al. 2009, Hedd et al. 2014, Quillfeldt et al. 2014, but see Pinet et al. 2012). Moreover, given the exceptionally high 
nesting density at South Georgia, loss of the territory to conspecifics is more likely if the breeding site is unattended for longer periods, suggesting it may be beneficial for one member of the pair to remain close to the colony. Indeed, high attendance rates and fewer joint nest absences have been reported for skuas at South Georgia during incubation and chickrearing when compared to sites elsewhere (Pietz 1987, Catry \& Furness 1999, Caldow \& Furness 2000, Carneiro et al. 2014).

\section{At-sea activity patterns}

Brown skuas spend much less time flying during the non-breeding and pre-laying periods than albatrosses and petrels, particularly during daylight (Phillips et al. 2007, present study). The number of flight bouts per day was surprisingly low. This suggests that birds may forage opportunistically using a sit-and-wait strategy as previously described for other species, including white-chinned petrels Procellaria aequinoctialis, grey-headed albatrosses Thalassarche chrysostoma, and Desertas petrels Pterodroma deserta (Catry et al. 2004, Mackley et al. 2010, Péron et al. 2010, Ramírez et al. 2013). Alternatively, brown skuas may feed on large items of carrion or moribund prey, as they do on land during the breeding season (Phillips et al. 2004a, Anderson et al. 2009, Carneiro et al. 2014). Amongst procellariids, the species with activity patterns during the non-breeding season that are most similar (i.e. low flight activity) to those of wintering brown skuas are wandering albatrosses and white-chinned petrels, which to some extent also rely on scavenging (Xavier et al. 2004, Mackley et al. 2010, 2011). These 2 species nonetheless spend considerably more time in flight, possibly because they use dynamic soaring to reduce flight costs, whereas skuas usually flap continuously in cruising flight and so would expend more energy if travelling long distances between prey patches (Pennycuick 1987, Catry et al. 2011, Gutowsky et al. 2014).

Although both sexes were more active during daylight, females spent proportionally more time flying during darkness than males in the non-breeding season. This reflects their longer, but not more frequent, flight bouts. As females have higher wing loading and less manoeuvrability than males (Phillips et al. 2002, Carneiro et al. 2014), they might land less frequently because of the greater cost of taking off (Shaffer et al. 2001, Phillips et al. 2004c). The greater manoeuvrability of males would also be an advan- tage during daylight when feeding by kleptoparasitism (Phillips et al. 2002), but the limited time spent flying suggests that either this foraging mode is rare, or that when used, it is highly successful. Although in theory, darkness should tend to limit movements, as aerial detection and capture of prey is more difficult (Phalan et al. 2007, Mackley et al. 2011), this seems not to affect females to the same degree as males, but it could explain their longer flight durations at night. The number of flight bouts per day during the prelaying exodus was also higher for females, suggesting that they increase their foraging effort to acquire enough resources for egg formation.

\section{CONCLUSIONS}

Although seabird distributions are expected to vary temporally and spatially according to the dynamic nature of the marine environment, the population of brown skuas tracked from South Georgia during migration and the pre-laying exodus visited the same general area and showed similar habitat preferences between 2002 and 2012. They preferred habitats associated with static features (i.e. bathymetry), which may explain the consistency found between years. Further studies comparing years of contrasting foraging conditions would reveal whether skuas are able to change their foraging strategies to compensate for environmental changes. In addition, this study highlighted the need for large sample sizes to detect strategies used by a small proportion of the population. The existence of multiple non-breeding destinations may be advantageous given increasing anthropogenic impacts on marine ecosystems.

Acknowledgements. We thank Ben Phalan, Ruth Brown and Jenny James for help with fieldwork on Bird Island, and the South Georgia Heritage Trust and Government of South Georgia and the South Sandwich Islands for part-funding the study. This study represents a contribution to the Ecosystems component of the British Antarctic Survey Polar Science for Planet Earth Programme, funded by The Natural Environment Research Council. The Coordenação de Aperfeiçoamento de Pessoal de Nível Superior (CAPES) and Cambridge Overseas Trust (COT) provided a scholarship to A.P.B.C. Comments from 4 anonymous reviewers improved the manuscript.

\section{LITERATURE CITED}

Aarts G, MacKenzie M, McConnell B, Fedak M, Matthiopoulos J (2008) Estimating space-use and habitat preference from wildlife telemetry data. Ecography 31:140-160 
Anderson ORJ, Phillips RA, Shore RF, McGill RAR, McDonald RA, Bearhop S (2009) Diet, individual specialisation and breeding of brown skuas (Catharacta antarctica lonnbergi): an investigation using stable isotopes. Polar Biol 32:27-33

Arnold TW (2010) Uninformative parameters and model selection using Akaike's information criterion. J Wildl Manag 74:1175-1178

Barbraud C, Weimerskirch H (2006) Antarctic birds breed later in response to climate change. Proc Natl Acad Sci USA 103:6248-6251

Block BA, Jonsen ID, Jorgensen SJ, Winship AJ and others (2011) Tracking apex marine predator movements in a dynamic ocean. Nature 475:86-90

Bogdanova MI, Daunt F, Newell M, Phillips RA, Harris MP, Wanless S (2011) Seasonal interactions in the blacklegged kittiwake, Rissa tridactyla: links between breeding performance and winter distribution. Proc R Soc B 278:2412-2418

> Bogdanova MI, Wanless S, Harris MP, Lindström J and others (2014) Among-year and within-population variation in foraging distribution of European shags Phalacrocorax aristotelis over two decades: implications for marine spatial planning. Biol Conserv 170:292-299

Bost CA, Cotté C, Bailleul F, Cherel Y and others (2009) The importance of oceanographic fronts to marine birds and mammals of the southern oceans. J Mar Syst 78:363-376

Burnham KP, Anderson DR (2002) Model selection and multimodel inference: a practical information-theoretic approach. Springer Science \& Business Media, New York, NY

Burton RW (1968) Breeding biology of the brown skua, Catharacta skua lonnbergi (Mathews), at Signy Island, South Orkney Island. Br Antarct Surv Bull 15:9-28

> Caldow RWG, Furness RW (2000) The effect of food availability on the foraging behaviour of breeding great skuas Catharacta skua and Arctic skuas Stercorarius parasiticus. J Avian Biol 31:367-375

Calenge C (2006) The package 'adehabitat' for the R software: a tool for the analysis of space and habitat use by animals. Ecol Model 197:516-519

Carneiro APB, Manica A, Phillips RA (2014) Foraging behaviour and habitat use by brown skuas Stercorarius lonnbergi breeding at South Georgia. Mar Biol 161: 1755-1764

Carneiro APB, Manica A, Trivelpiece WZ, Phillips RA (2015) Flexibility in foraging strategies of brown skuas in response to local and seasonal dietary constraints. J Ornithol 156:625-633

> Catry P, Furness R (1999) The influence of adult age on territorial attendance by breeding great skuas Catharacta skua: an experimental study. J Avian Biol 30:399-406

> Catry P, Phillips RA, Phalan B, Silk JRD, Croxall JP (2004) Foraging strategies of grey-headed albatrosses Thalassarche chrysostoma: integration of movements, activity and feeding events. Mar Ecol Prog Ser 280:261-273

Catry P, Dias MP, Phillips RA, Granadeiro JP (2011) Different means to the same end: long-distance migrant seabirds from two colonies differ in behaviour, despite common wintering grounds. PLoS ONE 6:e26079

- Catry P, Dias MP, Phillips RA, Granadeiro JP (2013a) Carryover effects from breeding modulate the annual cycle of a long-distance migrant: an experimental demonstration. Ecology 94:1230-1235

Catry P, Lemos RT, Brickle P, Phillips RA, Matias R,
Granadeiro JP (2013b) Predicting the distribution of a threatened albatross: the importance of competition, fisheries and annual variability. Prog Oceanogr 110:1-10

Ceia FR, Phillips RA, Ramos JA, Cherel Y, Vieira RP, Richard P, Xavier JC (2012) Short- and long-term consistency in the foraging niche of wandering albatrosses. Mar Biol 159:1581-1591

> Cleasby IR, Wakefield ED, Bodey TW, Davies RD and others (2015) Sexual segregation in a wide-ranging marine predator is a consequence of habitat selection. Mar Ecol Prog Ser 518:1-12

Copello S, Seco Pon JP, Favero M (2013) Use of marine space by black-browed albatrosses during the nonbreeding season in the southwest Atlantic Ocean. Estuar Coast Shelf Sci 123:34-38

Croxall JP, Wood AG (2002) The importance of the Patagonian Shelf for top predator species breeding at South Georgia. Aquat Conserv 12:101-118

Croxall JP, Silk JRD, Phillips RA, Afanasyev V, Briggs DR (2005) Global circumnavigations: tracking year-round ranges of nonbreeding albatrosses. Science 307:249-250

> Dias MP, Granadeiro JP, Phillips RA, Alonso H, Catry P (2011) Breaking the routine: individual Cory's shearwaters shift winter destinations between hemispheres and across ocean basins. Proc R Soc B 278:1786-1793

Fieberg J, Kochanny CO (2005) Quantifying home-range overlap: the importance of the utilization distribution. J Wildl Manag 69:1346-1359

Frederiksen M, Moe B, Daunt F, Phillips RA and others (2012) Multicolony tracking reveals the winter distribution of a pelagic seabird on an ocean basin scale. Divers Distrib 18:530-542

Furness RW (1987) The skuas. T and AD Poyser, Calton

> Gilg O, Moe B, Hanssen SA, Schmidt NM and others (2013) Trans-equatorial migration routes, staging sites and wintering areas of a high-Arctic avian predator: the longtailed skua (Stercorarius longicaudus). PLoS ONE 8: e64614

Grecian WJ, McGill RAR, Phillips RA, Ryan PG, Furness RW (2015) Quantifying variation in $\delta^{13} \mathrm{C}$ and $\delta^{15} \mathrm{~N}$ isotopes within and between feathers and individuals: Is one sample enough? Mar Biol 162:733-741

Guilford T, Meade J, Willis J, Phillips RA and others (2009) Migration and stopover in a small pelagic seabird, the Manx shearwater Puffinus puffinus: insights from machine learning. Proc R Soc B 276:1215-1223

Guilford T, Freeman R, Boyle D, Dean B, Kirk H, Phillips R, Perrins C (2011) A dispersive migration in the Atlantic puffin and its implications for migratory navigation. PLoS ONE 6:e21336

Gutowsky SE, Gutowsky LF, Jonsen ID, Leonard ML, Naughton MB, Romano MD, Shaffer SA (2014) Daily activity budgets reveal a quasi-flightless stage during non-breeding in Hawaiian albatrosses. Mov Ecol 2:23-36

> Hedd A, Montevecchi WA, Phillips RA, Fifield DA (2014) Seasonal sexual segregation by monomorphic sooty shearwaters Puffinus griseus reflects different reproductive roles during the pre-laying period. PLoS ONE 9: e85572

> Hindell MA, Bradshaw CJA, Sumner MD, Michael KJ, Burton HR (2003) Dispersal of female southern elephant seals and their prey consumption during the austral summer: relevance to management and oceanographic zones. J Appl Ecol 40:703-715

Jiménez S, Domingo A, Brazeiro A, Defeo O and others (2016) 
Sex-related variation in the vulnerability of wandering albatrosses to pelagic longline fleets. Anim Conserv 19: 281-295

> Jonsen ID, Basson M, Bestley S, Bravington MV and others (2013) State-space models for bio-loggers: a methodological road map. Deep-Sea Res II 88-89:34-46

Jonsen ID, Luque S, Winship A, Pedersen MW (2015) bsam: Bayesian state-space models for animal movement. $\mathrm{R}$ package version 0.43.1. http://web.science.mq.edu.au/ ijonsen/code.html

Kappes MA, Shaffer SA, Tremblay Y, Foley DG and others (2010) Hawaiian albatrosses track interannual variability of marine habitats in the north Pacific. Prog Oceanogr 86: 246-260

Kopp M, Peter HU, Mustafa O, Lisovski S, Ritz MS, Phillips RA, Hahn S (2011) South polar skuas from a single breeding population overwinter in different oceans though show similar migration patterns. Mar Ecol Prog Ser 435:263-267

> Lascelles BG, Taylor PR, Miller MGR, Dias MP and others (2016) Applying global criteria to tracking data to define important areas for marine conservation. Divers Distrib 22:422-431

Louzao M, Navarro J, Forero MG, Igual JM, Genovart M, Hobson KA, Oro D (2011a) Exploiting the closest productive area: geographical segregation of foraging grounds in a critically endangered seabird. Mar Ecol Prog Ser 429:291-301

Louzao M, Pinaud D, Péron C, Delord K, Wiegand T, Weimerskirch H (2011b) Conserving pelagic habitats: seascape modelling of an oceanic top predator. J Appl Ecol 48:121-132

> Mackley EK, Phillips RA, Silk JRD, Wakefield ED, Afanasyev V, Fox JW, Furness RW (2010) Free as a bird? Activity patterns of albatrosses during the nonbreeding period. Mar Ecol Prog Ser 406:291-303

> Mackley EK, Phillips RA, Silk JRD, Wakefield ED, Afanasyev V, Furness RW (2011) At-sea activity patterns of breeding and nonbreeding white-chinned petrels Procellaria aequinoctialis from South Georgia. Mar Biol 158: 429-438

Magnusdottir E, Leat EHK, Bourgeon S, Strøm H and others (2012) Wintering areas of great skuas Stercorarius skua breeding in Scotland, Iceland and Norway. Bird Study 59:1-9

> Mannocci L, Laran S, Monestiez P, Dorémus G, Van Canneyt O, Watremez P, Ridoux V (2014) Predicting top predator habitats in the southwest Indian Ocean. Ecography 37:261-278

McFarlane Tranquilla LAM, Montevecchi WA, Hedd A, Fifield DA and others (2013) Multiple-colony winter habitat use by murres Uria spp. in the Northwest Atlantic Ocean: implications for marine risk assessment. Mar Ecol Prog Ser 472:287-303

Nur N, Jahncke J, Herzog MP, Howar J and others (2011) Where the wild things are: predicting hotspots of seabird aggregations in the California Current System. Ecol Appl 21:2241-2257

Oksanen J, Blanchet FG, Kindt R, Legendre P and others (2015) vegan: Community Ecology Package. R package version 2.4-0. https://cran.r-project.org/web/packages/ vegan/index.html

Paiva V, Geraldes P, Ramírez I, Meirinho A, Garthe S, Ramos J (2010a) Oceanographic characteristics of areas used by Cory's shearwaters during short and long foraging trips in the North Atlantic. Mar Biol 157:1385-1399

Paiva VH, Xavier J, Geraldes P, Ramirez I, Garthe S, Ramos JA (2010b) Foraging ecology of Cory's shearwaters in different oceanic environments of the North Atlantic. Mar Ecol Prog Ser 410:257-268

Pearce J, Ferrier S (2000) Evaluating the predictive performance of habitat models developed using logistic regression. Ecol Model 133:225-245

Pennycuick CJ (1987) Flight of auks (Alcidae) and other northern seabirds compared with southern Procellariiformes: Ornithodolite observations. J Exp Biol 128: 335-347

> Péron C, Delord K, Phillips RA, Charbonnier Y, Marteau C, Louzao M, Weimerskirch H (2010) Seasonal variation in oceanographic habitat and behaviour of white-chinned petrels Procellaria aequinoctialis from Kerguelen Island. Mar Ecol Prog Ser 416:267-284

> Phalan B, Phillips RA, Silk JRD, Afanasyev V and others (2007) Foraging behaviour of four albatross species by night and day. Mar Ecol Prog Ser 340:271-286

Phillips RA, Dawson DA, Ross DJ (2002) Mating patterns and reversed size dimorphism in southern skuas (Stercorarius skua lonnbergi). Auk 119:858-863

Phillips RA, Phalan B, Forster IP (2004a) Diet and long-term changes in population size and productivity of brown skuas Catharacta antarctica lonnbergi at Bird Island, South Georgia. Polar Biol 27:555-561

> Phillips RA, Silk JRD, Croxall JP, Afanasyev V, Briggs DR (2004b) Accuracy of geolocation estimates for flying seabirds. Mar Ecol Prog Ser 266:265-272

Phillips RA, Silk JRD, Phalan B, Catry P, Croxall JP (2004c) Seasonal sexual segregation in two Thalassarche albatross species: competitive exclusion, reproductive role specialization or foraging niche divergence? Proc R Soc Lond Ser B Biol Sci 271:1283-1291

> Phillips RA, Silk JRD, Croxall JP, Afanasyev V, Bennett VJ (2005) Summer distribution and migration of nonbreeding albatrosses: individual consistencies and implications for conservation. Ecology 86:2386-2396

Phillips RA, Silk JRD, Croxall JP, Afanasyev V (2006) Yearround distribution of white-chinned petrels from South Georgia: relationships with oceanography and fisheries. Biol Conserv 129:336-347

Phillips RA, Catry P, Silk JRD, Bearhop S, McGill R, Afanasyev V, Strange IJ (2007) Movements, winter distribution and activity patterns of Falkland and brown skuas: insights from loggers and isotopes. Mar Ecol Prog Ser 345:281-291

Phillips RA, Croxall JP, Silk JRD, Briggs DR (2007) Foraging ecology of albatrosses and petrels from South Georgia: two decades of insights from tracking technologies. Aquat Conserv 17:S6-S21

> Phillips RA, Bearhop S, Mcgill RAR, Dawson DA (2009) Stable isotopes reveal individual variation in migration strategies and habitat preferences in a suite of seabirds during the nonbreeding period. Oecologia 160:795-806

Pietz PJ (1987) Feeding and nesting ecology of sympatric south polar and brown skuas. Auk 104:617-627

Pinaud D, Weimerskirch H (2005) Scale-dependent habitat use in a long-ranging central place predator. J Anim Ecol 74:852-863

> Pinaud D, Cherel Y, Weimerskirch H (2005) Effect of environmental variability on habitat selection, diet, provisioning behaviour and chick growth in yellow-nosed albatrosses. Mar Ecol Prog Ser 298:295-304 
Pinet $\mathrm{P}$, Jaquemet S, Pinaud D, Weimerskirch H, Phillips RA, Corre ML (2011) Migration, wintering distribution and habitat use of an endangered tropical seabird, Barau's petrel Pterodroma baraui. Mar Ecol Prog Ser 423: 291-302

Pinet P, Jaquemet S, Phillips RA, Le Corre M (2012) Sex-specific foraging strategies throughout the breeding season in a tropical, sexually monomorphic small petrel. Anim Behav 83:979-989

Pollet IL, Ronconi RA, Jonsen ID, Leonard ML, Taylor PD, Shutler D (2014) Foraging movements of Leach's stormpetrels Oceanodroma leucorhoa during incubation. J Avian Biol 45:305-314

Quillfeldt P, Masello JF, Navarro J, Phillips RA (2013) Yearround distribution suggests spatial segregation of two small petrel species in the south Atlantic. J Biogeogr 40: 430-441

Quillfeldt P, Phillips RA, Marx M, Masello JF (2014) Colony attendance and at-sea distribution of thin-billed prions during the early breeding season. J Avian Biol 45: 315-324

Quillfeldt P, Cherel Y, Masello JF, Delord K and others (2015) Half a world apart? Overlap in nonbreeding distributions of Atlantic and Indian Ocean thin-billed prions. PLoS ONE 10:e0125007

R Core Team (2014) R: a language and environment for statistical computing. R Foundation for Statistical Computing, Vienna

Ramírez I, Paiva VH, Fagundes I, Menezes D and others (2015) Conservation implications of consistent foraging and trophic ecology in a rare petrel species. Anim Conserv 19:139-152

Ramírez I, Paiva VH, Menezes D, Silva I, Phillips RA, Ramos JA, Garthe S (2013) Year-round distribution and habitat preferences of the Bugio petrel. Mar Ecol Prog Ser 476: 269-284

Raymond B, Lea MA, Patterson T, Andrews-Goff V and others (2015) Important marine habitat off east Antarctica revealed by two decades of multi-species predator tracking. Ecography 38:121-129

Rayner MJ, Taylor GA, Gummer HD, Phillips RA, Sagar PM, Shaffer SA, Thompson DR (2012) The breeding cycle, year-round distribution and activity patterns of the endangered Chatham petrel (Pterodroma axillaris). Emu 112:107-116

Roberts JJ, Best BD, Dunn DC, Treml EA, Halpin PN (2010) Marine Geospatial Ecology Tools: an integrated framework for ecological geoprocessing with ArcGIS, Python,

Editorial responsibility: Scott Shaffer, San Jose, California, USA
R, MATLAB, and C++. Environ Model Softw 25:1197-1207

Saraceno M, Provost C, Piola AR, Bava J, Gagliardini A (2004) Brazil Malvinas Frontal System as seen from 9 years of advanced very high resolution radiometer data. J Geophys Res 109:C05027, doi:10.1029/2003JC002127

Scales KL, Miller PI, Hawkes LA, Ingram SN, Sims DW, Votier SC (2014) On the front line: frontal zones as priority at-sea conservation areas for mobile marine vertebrates. J Appl Ecol 51:1575-1583

Shaffer SA, Weimerskirch H, Costa DP (2001) Functional significance of sexual dimorphism in wandering albatrosses, Diomedea exulans. Funct Ecol 15:203-210

Sittler B, Aebischer A, Gilg O (2011) Post-breeding migration of four long-tailed skuas (Stercorarius longicaudus) from north and east Greenland to west Africa. J Ornithol 152:375-381

> Soanes LM, Arnould JPY, Dodd SG, Sumner MD, Green JA (2013) How many seabirds do we need to track to define home-range area? J Appl Ecol 50:671-679

> Thiebot JB, Lescroel A, Pinaud D, Trathan PN, Bost CA (2011) Larger foraging range but similar habitat selection in non-breeding versus breeding sub-Antarctic penguins. Antarct Sci 23:117-126

Wakefield ED, Phillips RA, Matthiopoulos J (2009) Quantifying habitat use and preferences of pelagic seabirds using individual movement data: a review. Mar Ecol Prog Ser 391:165-182

> Wakefield ED, Phillips RA, Trathan PN, Arata J and others (2011) Habitat preference, accessibility, and competition limit the global distribution of breeding black-browed albatrosses. Ecol Monogr 81:141-167

> Winship AJ, Jorgensen SJ, Shaffer SA, Jonsen ID, Robinson PW, Costa DP, Block BA (2012) State-space framework for estimating measurement error from double-tagging telemetry experiments. Methods Ecol Evol 3:291-302

Wood S (2006) Generalized additive models: an introduction with R. CRC Press, Boca Raton, FL

Xavier JC, Trathan PN, Croxall JP, Wood AG, Podestá G, Rodhouse PG (2004) Foraging ecology and interactions with fisheries of wandering albatrosses (Diomedea exulans) breeding at South Georgia. Fish Oceanogr 13: $324-344$

Yamamoto T, Takahashi A, Sato K, Oka N, Yamamoto M, Trathan PN (2014) Individual consistency in migratory behaviour of a pelagic seabird. Behaviour 151:683-701

Žydelis R, Lewison RL, Shaffer SA, Moore JE and others (2011) Dynamic habitat models: using telemetry data to project fisheries bycatch. Proc R Soc B 278:3191-3200

Submitted: November 30, 2015; Accepted: May 20, 2016 Proofs received from author(s): July 9, 2016 